N. CheKh, D. Vershynina, A. LuB

\title{
THE MAIN RISKS OF ECONOMIC SECURITY OF THE CONSTRUCTION INDUSTRY ENTERPRISES, THEIR IDENTIFICATION AND MANAGEMENT
}

In the conditions of an unstable economic environment, the main task of the management of enterprises in the construction industry is to adapt the changing of the external conditions and the reducing of negative factors influence on the activity and its financial results. The uncertainty of the influence of environmental factors and the lack of opportunity to make a reliable forecast of economic processes in the industry give rise to risk. The uncertainty factor has a significant impact on the activity of construction companies, which determines the urgency of the task of increasing the effectiveness of risk management at all stages of the life cycle of construction products. The subject of the study in this paper is the peculiarities of the activities of construction enterprises and their economic security. The construction industry is the core of the entire national industry, in comparison with other types of economic activity; it has a number of advantages, namely: consolidation, real estate, capital intensity, material content, duration of creation and operation, etc. Compared to many other industries, construction is a specific type of design industry with certain characteristics that affect the characteristics of the built-in products, the modes of production and industry. The objective of the article is to identify the main risks of the economic security system of the construction company and analyze the ways of their identification and evaluation. The purpose of article is to identify the main risks of the economic security system of the construction company and analyze the ways of their identification and management. The goal of this research is to develop an author's approach to classifying the risks of economic safety of construction industry enterprises and to develop recommendations on identifying and managing risks. Using the general logical-analytical methods, this article explores the nature of the characteristics of the enterprises of construction and industry of various types of risks associated with it. As a result, the authors proposed to distinguish legal, financial, architectural and construction (production), natural (ecological) and risks on the real estate market as the main risks of economic safety of the enterprises of the construction industry. Conclusions regarding the main features of the activity of construction enterprises and nature of risks in their functioning are made.

Keywords: economic security; construction; risks; financial risks; construction companies; fraud.

\section{Introduction}

The construction industry is one of the sectors of the economy that is the most sensitive to the dynamic changes, and, at the same time, it has a significant impact on the development of the entire Ukrainian economy. The construction sector, in addition to financial services and export-oriented manufacturing, was hit hardest by the economic crisis of 2008-2009. The construction industry of Ukraine begun to recover the pre-crisis capacities only since the end of 2016. Volume of sales of construction works and products, the number of employed workers at the enterprises of the branch, profitability and the volume of own capital increased compared to the previous year.

There are also positive trends in the development of the construction sector in Europe. The European Construction Industry Federation (FIEC) in its annual report noted that the construction activity across the EU increased by $2.2 \%$ in 2016 (reaching 1278 billion Euros) compared to 2015. In 2018, even more growth was projected - by $3 \%$ compared to the previous year (forecast at 1.343 billion euros).

Nevertheless, in spite of positive forecasts and trends, in their activity, construction companies are forced to withstand a number of risks that can negatively affect their level of economic security and, consequently, the results of their operation.

\section{Analysis of literary sources and problem statement}

Problems of economic safety of construction organizations in their work considered Andrienko V.M., Vasiliev V.M., Panibratov Yu.P., Molodid O.O., Vakhovich I.V., Karpova K.V., Kushniruk A.O.,
Lagutina Z.V. etc. Despite the research carried out, the issues of classification of the main risks of economic safety of construction enterprises remain insufficiently high; taking into account the European integration course of Ukraine and the key role of the construction sector in the national economy becomes especially relevant.

\section{Aims and objectives of the study}

The purpose of the article is to determine the main risks of the economic security system of a construction company and to develop a comprehensive risk classification that would take into account both the features of the construction industry and the European integration expectations of Ukraine.

\section{Materials and methods of research}

To achieve this goal, the results of international surveys and studies are used, the relevant researches of the well-known scientists are analyzed, and the logicalanalytical and visual general methods are applied.

\section{Research results and discussions}

Euro integration remains the main foreign policy priority of Ukraine, which is connected with the advantages of recognizing the status of the state as a European one. These include the provision of small and medium-sized businesses, the introduction of EU standards, macroeconomic stability, additional investment in the country's economy, the use of new technologies, etc.

For construction companies, this means the potential 
development of the industry and the corresponding increase in the efficiency of their activities. However, in order to take the full advantage of the opportunities opened up by the European integration, construction companies need to understand the risks that may arise in the course of their activities, as well as at the global markets.

The economic security of the construction industry enterprises is of particular importance for the state, society and citizens taking into account the peculiarities of the construction industry, its importance for the national economy and the general instability of the national economy. The economic security of the building industry companies is understood as a system of guarantees and measures to ensure the protection of corporate resources, strategic goals and interests of the enterprise, as well as timely and adequate response to the signals and threats to its external and internal environment. Accordingly, the risk of economic security of the construction industry is considered a possible event, the onset of which may lead to unwanted consequences for the company itself and other contract participants

The project production predominates in construction, and manufacturing organizations are formed with the relatively independent participants, that are the part of the ever-changing one-off coalitions of enterprises. This affects the structure and methods of the industry, which leads to a strong fragmentation of the sector with the different types of firms. As a result, the level of complexity of production in construction is relatively high, and the level of efficiency is relatively low.

Vasiliev V.M. and Panibratov Yu.P., considering the management of investment construction projects, distinguish risks depending on the affiliation with the enterprise. Accordingly, their classification includes investor risks, banking, leasing, issuer risks, and vendor risks [1].

Karpova K. V., considering threats to economic security of construction companies as a set of certain negative factors, groups them in the following areas:

- threats to material resources;

- threats to financial resources;

- threats to the safety of production technologies;

- threats to commercial activities;

- management threats [2].

Kushniruk A. A. also considers various risks in the activities of construction enterprises, but does not provide any criteria or signs by which they could be grouped and generally analyzes the risks that are characteristic of any enterprise [3].

Andrienko V.M. identifies specific types of threats in the construction industry, such as: orders;

- aggravation of competition on a limited market of

- aggravation of competition in a limited geographic area;

- unfair competition in all its manifestations;

- monopolization of the market by large construction companies;

- corruption relations in the distribution of state and municipal orders;
- the phenomenon of commercial bribery in obtaining orders and distribution of subcontractors, socalled "rollback" and "back rollback";

- internal fraud.

- damage to the object of construction, engineering, damage to inventory;

- damage to personnel (occupational injuries);

- the threat of the appearance of a defect, including hidden, in work performed by the forces of subcontractors, as well as due to a low quality of used building materials;

- the threat of the appearance of a marriage, including a hidden one, in works performed by one's own forces;

- the threat of a shortage due to poor quality of project organizations, as well as general contractors [4].

Although the author emphasizes the specifics of the enterprises of the construction industry, in our opinion, the current list is incomplete and does not take into account the features of the financial component of the economic security of the construction company.

Construction is a risky business. Each construction project is unique and involves a set of problems and opportunities. Detection and risk management can be complex, but not impossible, with careful planning and execution. When the risk turns into reality, it can disrupt the project. In order to avoid disaster, you should be able to properly assess, control and manage the risks after their detection.

Risks are not always negative. The ability to effectively identify and manage risks can increase profits, build good customer relationships, which will increase the number of projects and expand the business to new markets and sectors.

Among the reasons hindering the development of construction activities in Ukraine, the following are often referred:

1) insecurity with financial resources; 2) lack of working capital; 3) lack of orders for construction work; 4) reducing the solvency of consumers; 5) nontransparency of legislation and high level of bureaucratization; 6) high tax pressure and so on.

Serdyuk T.V. and Sologor V.M. emphasize that the scope of real estate transactions, in general, is subject to risks, which is exacerbated by the special vulnerability of objects of unfinished construction. At the same time, among the reasons for the existence of high risk in the construction sector, the following should be mentioned: the location of the real estate market, its direct dependence on the regional and global economic situation, low liquidity of the new buildings in the absence of a real mechanism of mortgage lending, a large amount of funds involved in the construction process, duration of investment and dependence of the final result upon the economic and political situation in the country [5].

In addition, in comparison with the many other industries, construction is a specific type of project industry with certain characteristics that affect the characteristics of built products, methods of production and industry. Let us consider the main features of the 
activities of construction companies that can affect the level of their economic security.

First of all, the activity of construction industry enterprises is largely regulated by the state. They operate based on a license, the start of construction requires obtaining a design permit, the construction process itself requires coordination with a number of services, and verification of compliance with standards and specifications, and the state has an impact on the pricing structure of the construction industry. With the entry of Ukraine into the European space, domestic construction companies are waiting for changes in legislation and the transition to a new level of technical regulation in construction. Ukraine is constantly reviewing and implementing new state building codes (DBN). In 2019, it is planned to revise $30 \mathrm{DBNs}$, which will enable the introduction of effective innovations, while on the other hand will force construction companies to make changes to their activities [6].

Minister of Regional Development, Construction and Housing and Communal Services of Ukraine G. Zubko notes that the main risk to the development of the construction industry is corruption that occurs at different stages of the procedure: from obtaining a license to commissioning a construction site [2]. The indicated problem occurs both at the stage of commissioning of the object and during the procedures for approval of the design documentation and the allocation of land for construction. The presence of additional unofficial costs forces the owners of construction companies to go on illegal actions to fulfill the obligations that were taken to the customers in the stipulated terms [7].

In addition, construction as a licensed activity is associated with the threats of administrative pressure on the management of the company, both by officials and competitors.

Another risk in the activities of the construction industry is the risk of non-compliance with the terms of the contract. Because construction companies operate in conditions of constant uncertainty and environment variability, the probability of breach of contractual terms both from third parties and from the enterprise, itself is very high. For example, a supplier may delay the delivery of materials, or deliver materials of poor quality, or the contractor may not perform scheduled construction and installation work in time, thereby delaying the construction of the property. Accordingly, the delaying of the construction, as well as other violations of contractual conditions, causes the financial losses of the construction company.

Consequently, it is advisable to take into account the following legal risks: administrative barriers, high level of corruption, dynamic changes in the legislation, violation of licensing conditions, non-compliance with European standards, pressure from the controlling authorities, breach of contract conditions, unfair counteraction behavior, pressure from creditors, lack or non-compliance of the technical documentation.

The construction industry, possibly more than any other, is associated with the emergence of financial risks [8]. The directions of their occurrence may be both from investors, developers, and from the side of specialized contractors.

The configuration of financial risks is caused by many factors: the duration of the construction cycle; high capital intensity of products; involving third parties (usually financial intermediaries) to execute an investment project; limited resources; limited number of projects carried out simultaneously, investment dependence, availability of external conditions including the inflationary processes, permanent change in the taxation regime.

Construction is an industry that requires significant financial resources. That is why we need to use the constant sources that would allow us to attract the additional funds. As a rule, owners do not have the desire to risk their own capital in building real estate, translating financial risks to investors, which makes the construction industry dependent on investments and sources of additional capital (for example, bank loans).

The next problem related to the lack of information is the inability to obtain a complete package of information from the developer the quality of materials, reliability and durability of structures, future dates and cost of repairs. This leads to the fact that investors cannot fully appreciate the investment attractiveness of the object.

The pricing problem is that buyers cannot get proven information about upcoming operating costs in advance. This is partly because ministries do not have directories of current market prices. Instead, they use outdated resource costs. This makes it possible to enter any amount in the estimates, creating a "backlash" for corruption. In addition, Ukraine is offered to determine the cost of design as a percentage of the cost of construction. However, it is determined by the project itself. This encourages an increase in the value of an object rather than being oriented towards its effectiveness.

In addition, among the characteristics of the activity of construction enterprises the following can be distinguished: the high level of competition in the industry, considerable unprofitableness of construction enterprises and, in general, the industry sensitivity to economic changes and its dependence on demand [9].

As construction work is a long process that takes very often not more than one calendar year, it is not always possible to determine the demand for construction products and predict changes in market conditions at the time of commissioning of the facility. This threat entails the risk not only of obtaining less profit from the enterprise, compared with the planned but possibly full loss of investment in the project.

In addition, the involvement of a large number of participants in the implementation of the construction project and a large amount of capital spent on its implementation, the construction industry is considered an area for which fraudulent schemes are typical. According to the ACFE, the share of financial losses in the budget of a construction project caused by inefficient spending, misappropriation of assets, and fraud could reach $45 \%$ [10]. 
Typical fraudulent schemes are:

- excessive prices in orders for change of volumes of works;

- manipulation of completion reports;

- an increase in the volume of construction and costs, including - due to the introduction of fictitious papers into the acts of inspection of hidden works (for example, on the foundation);

- manipulation of write-off rates and reports on the use of materials;

- services of fictitious vehicles and equipment;

- excess of the required volume of purchases and fictitious purchases from affiliated companies;

- sale of fixed assets and materials at a price below market, including on credit;

- issuance of outstanding advances and financial assistance;

- financial leasing at overcharged rates through intermediary companies; souls";

- excessive labour costs of the project and "dead

- unpaid bills of subcontractors [11].

Thus, it is expedient to include the following financial risks: changes in exchange rates, inflation rate rise, interest rate changes, lack or incorrect design estimates, growth of accounts receivable and payables, fraud.

Concerning the features of production, it is expedient to allocate the uniformity of construction production, the volume and duration of production, labour intensity, significant social responsibility for the product created, a conservatism of the industry, the cyclicality of production, and dependence on suppliers of raw materials.

Performance of construction work is always accompanied by the drawing up of appropriate plans for the fulfillment of obligations in accordance with the construction contract. Deviations in work plans, changes in technology or errors in the technical documentation may lead to over-expenditures or contract breach.

The greatest risks that may arise in this area are design flaws and changes that need to be made after the start of construction. The design may be incomplete, inadequate or incorrect, and therefore the project cannot be constructed. In addition, there may be an additional risk of delay in the delivery of construction plans [12].

In connection with the use of services of contractors and subcontractors in construction, it should be noted that while using the outsourcing construction company can generate profits, this practice can be at the same time risky. Low project performance may be achieved, which will delay the implementation of the whole project or lead to a breach of contract because of disputes between subcontractors and contractors that impede the implementation of the project.

The presence of strictly regulated conditions of construction, a set of software products, which are used to calculate complex formulas for determining various kinds of loads necessitate the presence of highly qualified personnel with practical and theoretical experience in the implementation of projects that the company performs.

As a work activity, construction is characterized by an increased risk of work performed. This is due to the many reasons, such as:

- work at height;

- outdoor work (in particular, in unfavourable weather conditions);

- work with harmful and dangerous substances (including flammable and explosive materials);

- physically tense work connected with the rise of cargoes and a large number of displacements, etc. [13]

Here you can also add the need to use of a large number of different equipment, pneumatic and power tools, specialized vehicles and other units that require additional training of personnel who use them, and increased attention when working in the construction.

Thus, it is advisable to highlight the architectural and construction or production risks, which are manifested in the failure of the construction process, equipment failure, violation of the technology of construction works, involving construction workers and contractors with the low qualification, errors in design solutions and technical expertise, design changes, the use of outdated technologies and construction materials of poor quality, emergencies, violation of safety rules.

The next type of risk is natural (environmental) risks. Production in construction is always locally related and depends on physical factors such as soil and weather conditions. The natural risk in construction includes the natural disasters, accidents (including construction work), environmental pollution.

A specific type of risk for the construction industry is the risks connected with the real estate market. Features of the real estate market are its location, dependence on the state of the regional economy, low liquidity of the goods on the market, high capital market capitalization, as well as imperfection of the domestic legal framework for real estate transactions and the underdeveloped system of registration of rights to real estate and their transition, a significant gap between housing prices and incomes of the overwhelming majority of the population. In connection with them, construction companies often become objects of exposure to risks in the real estate market. These risks include changes in market conditions and prices, the emergence of alternative market proposals, increased competition, local changes in legislation and the economy.

However, the risks of economic safety of construction enterprises should be grouped into five main groups according to their nature and origin (Fig. 1). Such a classification helps to understand better the nature of these risks because it is based on their origin.

The presence of such a number of risks and their diversification requires the use of a set of management measures for these risks, they should include:

- identification of risks that are possible during a particular transaction or real estate transaction;

- qualitative and quantitative risk analysis (definition of the causes of risks and factors of increasing their probability of occurrence, stages of processes at which there may be a risk; 
- definition of possible sizes of losses caused by this or that risk);

- determination of the possibilities of reducing the risk and expenses necessary for its prevention;
- development and implementation of measures to prevent risks, reduce the probability of their occurrence or possible losses;

- control over the implementation of necessary measures; making meaningful changes in the mechanism of their implementation.

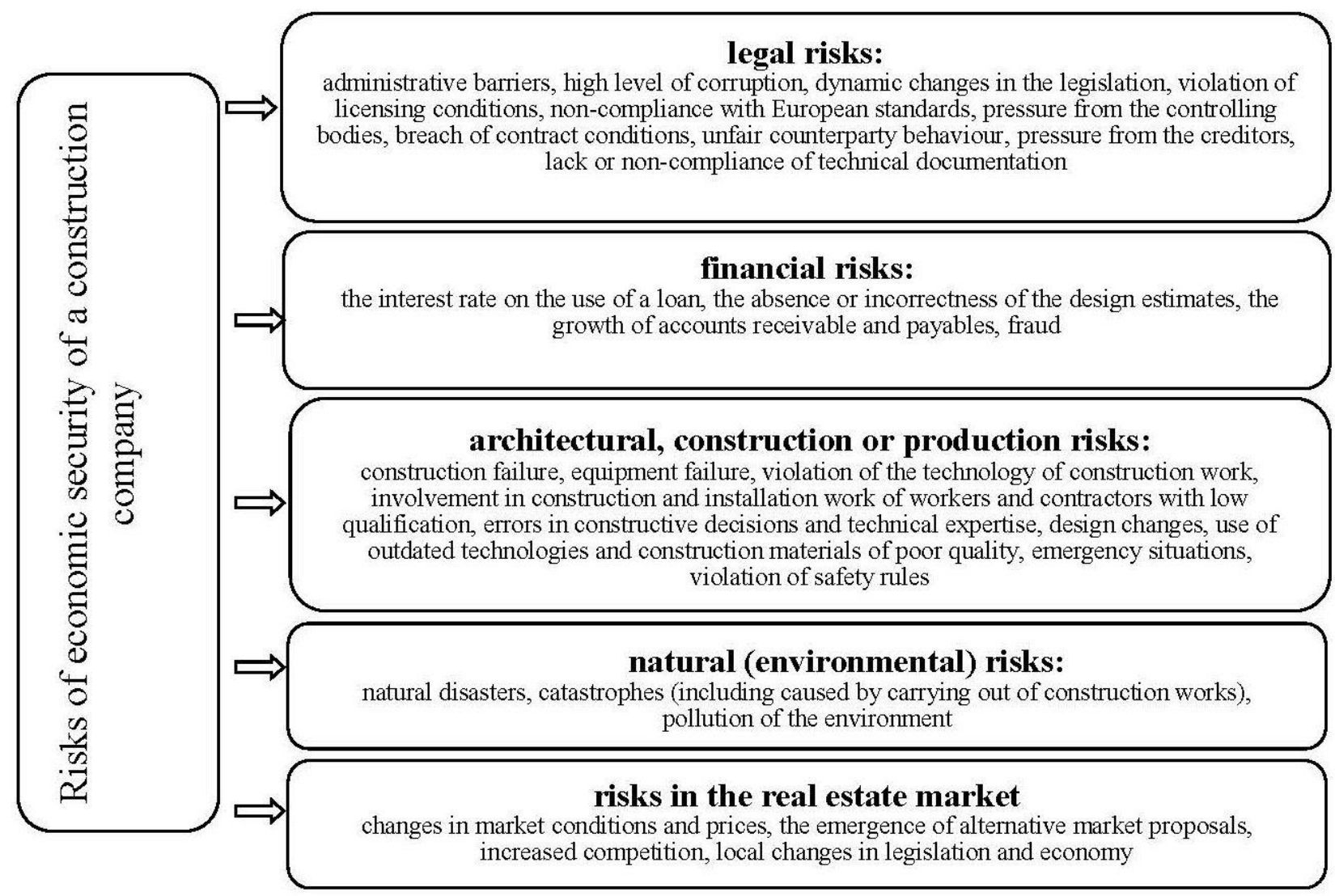

Fig. 1. Classification of risks of economic safety of a construction company by their origin

Circumstances that complicate the timely detection and prevention of risks in the construction industry can be considered the following:

- the environment of permissiveness and mutual guarantee;

- lack of proper accounting and control;

- the practice of decision-making without proper informational and analytical support of this process;

- limited access to the documents of the security company's employees;

- the lack of proper control and monitoring of the activity of the construction company as a whole, and the factors of threats, in particular.

Despite these circumstances, the identification of risks is a key step in managing and minimizing risks [14]. The main measures aimed at timely identification and response to the risks of economic security in the construction industry should be:

- analysis of the local real estate market and the situation in the industry;

- carrying out a competitive selection of project participants;

- the involvement of competent lawyers and builders for the preparation and conclusion of contracts with contractors and other market players;
- order in the law firm to conduct an examination of the rights of the contracting parties and contracts;

- introduction of a risk management system and its minimization;

- customer satisfaction analysis, work with regular, verified suppliers and contractors;

- strengthened control over the timing of the work, the creation of a reserve of capacities;

- elimination of the probable reasons for the breach of contracts;

- systematic training of employees and managers.

As to the steps to be taken to identify the risks and threats, it is important to point out that complete elimination or elimination of risks in the construction sector is practically impossible. Therefore, the main task of risk management should be to transfer them from one side to another through contractual provisions. Therefore, it is very important to identify them primarily to reduce the risks. Once this is done, it is possible to take measures aimed at preserving control and preventing possible negative consequences.

The response strategy and the choice of approach depend on the type of risk. Among the responses, it is advisable to distinguish: 
- Avoidance of risk - the risk can be rejected by eliminating the risk, project execution in another direction, while at the same time continuing to achieve the set goals of the project. Changing the project management plan to eliminate the threat, isolating project objectives from the risk, or weaken project objectives that could lead to losses, such as increasing schedule times or reducing sales volumes [15].

- Risk transfer - Risk transfer involves searching for the other party that is ready to assume responsibility for the management and is responsible for the risk in case of its occurrence. The transmission of the threat does not eliminate it; this threat still exists, but it belongs and is managed by the other party. Risk transfer can be an effective way to deal with financial risk. The purpose is to ensure that the risk belongs and is managed by the party that is able to cope with it most effectively.

- Risk mitigation/reduce - Mitigation reduces the likelihood and/or the impact of an adverse risk event to an acceptable level. The use of early measures to reduce the likelihood and/or exposure of the risk is often more effective than attempting to repair damage after the risk has occurred.

- Risk management - this strategy aims at eliminating the uncertainty associated with a certain positive risk, creating conditions for its implementation, eliminating the uncertainty associated with a certain positive risk. The opportunity is defined as a risk event, which, if it occurs, will have a positive effect on the achievement of the project objectives.

- Distribution of risk - the ability to share its own risk with the other party, which is best able to increase its probability of occurrence and potential benefits if it is realized. The transfer of threats and the distribution of opportunities is similar to the use of the third party to whom the threats are transmitted and which assumes the responsibility with which the opportunities and potential benefits are shared.

- Adoption of risk - Ultimately, it is impossible to eliminate all threats or take full advantage of opportunities. It is possible to document them and at least ensure that they are identified and identified. This strategy is adopted when it is not possible to react to the risk by other strategies, or the reaction is not justified by the great danger. When the manager and project team decide to take the risk, they agree to address the risk when it comes.

- Emergency plan - this involves using a backup plan if there is a risk. Emergencies can also be in the form of reserves for addressing unknown risks or in the form of costs for addressing unknown risks.
- Risk monitoring is the last stage of risk management. Once appropriate measures are implemented, it is advisable to track and record their effectiveness and any changes to the project risk profile. Whether the response measures have a positive or negative impact on the achievement of the project goals? Response and its consequences should be also documented for future reference and design plans.

Taking into account the specifics of construction work, insurance is another measure to prevent risks. Insurance of construction and installation risks allows a construction organization to remove the burden of possible additional costs that not only can significantly affect the profitability of the project but also to break all construction dates. Insurance coverage may include protection not only from classical hazards such as fire, natural disasters, and civil liability to third parties, etc. but also from the purely specific risks such as designer error, use of defective materials, personnel negligence, electric shock, etc.

\section{Conclusions}

In the conditions of an unstable economic environment, the main task of management of enterprises in the construction industry is to adapt to changing external conditions and reduce the manifestation of negative factors on the activity and its financial results. Uncertainty about the impact of environmental factors and the lack of opportunity to make a reliable forecast of economic processes in the industry give rise to the risk.

To identify and manage risks, it is necessary to know the types of risks inherent in the activities of construction companies. They can be legal, financial, architectural, construction, natural, risks in the real estate market, and can be caused by both internal and external sources. This classification reflects the nature of the risks to the economic safety of the construction enterprises and gives an understanding of their origin. The next step after a preliminary analysis of potential risks should be identifying and identifying these risks and their manifestations as a whole in the activities of the construction company, as well as within individual construction projects. Construction professionals' use the methods described in the management article but do not realize it. Working with risks in this field, construction should be complex and systemic in nature, which will minimize the impact of negative factors, and enhance the impact of positive.

\section{References}

1. Vasiliev, V. M., Panibratova, Yu. P. (1997), Management of construction investment projects : study guide [Upravlenie stroitelnymi investitsionnymi proektamy : uchebnoe posobie], Publishing of the DIA, Moscow, $307 \mathrm{p}$.

2. Karpova, K. V. (2015), "Analysis of threats to the economic safety of construction enterprises" [Analiz zagroz ekonomichnij bezpetsi budivelnyh pidpryjemstv"], Building manufacture, Vol. 58, P. 18-20.

3. Kushniruk, A. O. (2015), "Identification of internal and external threats to the system of economic safety of construction enterprises" ["Identyficatsia vnutrishnih ta zovnishnih zagroz systemi ekonomichnoi ,ezpeky budivelnych pidpryjemstv"], Ways of increasing the efficiency of construction in the conditions of formation of market relations, Vol. 33, P. 174-184.

4. Andrienko, V. (2012), "Specific types of threats and characteristics of economic security building enterprises" ["Spetsyfichni vydy zagroz ta osoblyvosti organizatsia zabezpechenia ekonomichnoi bezpeky budivelnych pidpryjemstv"], Effective Economics, No. 12 . 
5. Serdyuk, T. V., Solohor, V. M. (2017), "Risk Insurance in Construction" ["Strahuvania ryzykiv v bunivnytstvi"], Materials of XLVI Scientific and Technical Conference of VNTU Departments, Vinnytsya, March 22-24.

6. "The Ministry of Regional Development has approved new DBNs for the development of territories" ["Minregion zatverdyv novi DBN shcodo zabudovy terytorii"], available at: https://www.kmu.gov.ua/en/news/minregion-zatverdiv-novi-dbn-shodo-zabudoviteritorij

7. "The main risk for the construction industry is corrupt, - Zubko" ["Golovnyj ryzyk budivelnoi galuzi - koruptsijnyj, - Zubko"], available at : https://www.mk-oblrada.gov.ua/news.php?news=591\&group=23

8. Baloi, D. (2012), "Risk Analysis Techniques in Construction Engineering Projects", Journal of Risk analysis and crisis response, Vol. 2, Issue 2, P. 1-9.

9. Chekh, N. O., Vinnik, I. V. (2017), "Regulatory environment of business activities in Ukraine", Innovative Technologies and Scientific Solutions for Industries, Vol. 1 (1), P. 124-129, DOI: https://doi.org/10.30837/2522-9818.2017.1.124

10. Nasir, D., McCabe, B., Hartono, L. (2003), "Evaluating Risk in Construction-Construction Schedule Risk Model”, ASCE Journal of Construction Engineering and Management, Vol. 129, Issue 5, P. 518-527. DOI: https://doi.org/10.1061/(ASCE)07339364(2003)129:5(518)

11. "Construction Fraud: Ukrainian Realities" ["Shahraistvo v butivnytstvi: Ukrainski realii"], available at : https://www2.deloitte.com/ua/uk/pages/press-room/press-release/2018/fraud-on-construction.html

12. Lyons, T., Skitmore, M. (2004), "Project risk management in the Queensland engineering construction industry: a survey", International Journal of Project Management, Vol. 22, P. 51-61. DOI: https://doi.org/10.1016/S0263-7863(03)00005-X.

13. Smith, N. J., Merna, T., Jobling, P. (2006), Managing Risk in Construction Projects, 2nd Edition, Oxford : Blackwell Publishing, P. 1-56.

14. Ward, S. C. (2003), Project Risk Management: Process, Techniques and Insights, 2nd Edition, Chichester: John Wiley and Sons publication, 344 p., ISBN-13: 978-0470853559.

15. Chapman, C. B. (2013), "Risk management perspective on the project life cycle", International journal of Project Management, Vol. 13, Issue 3, P. 145-149. DOI: http://dx.doi.org/10.1016/0263-7863(95)00008-E.

Received 30.03.2019

Відомості про авторів / Сведения об авторах / About the Authors

Чех Наталія Олександрівна - кандидат економічних наук, Харківський національний університет міського господарства імені О. М. Бекетова, старший викладач кафедри фінансово-економічної безпеки, обліку і аудиту, Харків, Україна; e-mail: natariathebest@gmail.com; ORCID: https://orcid.org/0000-0001-5728-804X.

Чех Наталья Александровна - кандидат экономических наук, Харьковский национальный университет городского хозяйства имени А. Н. Бекетова, старший преподаватель кафедры финансово-экономической безопасности, учета и аудита, Харьков, Украина.

Chekh Nataliia - PhD (Economics Sciences), O. M. Beketov National University of Urban Economy in Kharkiv, Senior Lecturer of the Department of Financial and Economic Security, Accounting and Auditing, Kharkiv, Ukraine.

Вершиніна Дарина Миколаївна - Харківський національний університет міського господарства ім. О.М. Бекетова, аспірант кафедри фінансово-економічної безпеки, обліку і аудиту, Харків, Україна; е-mail: daryna1992v@gmail.com; ORCID: https://orcid.org/0000-0003-2336-7916.

Вершинина Дарина Николаевна - Харьковский национальный университет городского хозяйства им. А. Н. Бекетова, аспирант кафедры финансово-экономической безопасности, учета и аудита Харьков, Украина.

Vershynina Darina - O. M. Beketov National University of Urban Economy in Kharkiv, Graduate Student of the Department of Financial and Economic Security, Accounting and Audit, Kharkiv, Ukraine.

Луб Андрій Іванович - Харківський національний університет міського господарства ім. О. М. Бекетова, аспірант кафедри фінансово-економічної безпеки, обліку i аудиту, Харків, Україна; e-mail: alub6907@gmail.com; ORCID: https://orcid.org/0000-0001-9649-3476.

Луб Андрей Иванович - Харьковский национальный университет городского хозяйства им. А. Н. Бекетова, аспирант кафедры финансово-экономической безопасности, учета и аудита Харьков, Украина.

Lub Andrey - O. M. Beketov National University of Urban Economy in Kharkiv, Graduate Student of the Department of Financial and Economic Security, Accounting and Audit, Kharkiv, Ukraine.

\section{ОСНОВНІ РИЗИКИ ЕКОНОМІЧНОЇ БЕЗПЕКИ ПІДПРИСМСТВ БУДІВЕЛЬНОЇ ГАЛУЗІ, ЇХ ІДЕНТИФІКАЦІЯ ТА УПРАВЛІННЯ НИМИ}

В умовах нестабільного економічного середовища головним завданням менеджменту підприємств будівельної галузі стає пристосування до мінливих зовнішніх умов та зменшення прояву негативних факторів на діяльність та іiі фінансові результати. Невизначеність впливу факторів зовнішнього середовища та відсутність можливості здійснення достовірного прогнозу економічних процесів в галузі породжують ризик. Фактор невизначеності відіграє суттєвий вплив на діяльність будівельних підприємств, що обумовлює актуальність завдання підвищення ефективності управління ризиками на всіх стадіях життєвого циклу будівельної продукції. Предметом дослідження у цій роботі є особливості діяльності будівельних підприємств та їх економічна безпека. Будівельна галузь є серцевиною всієї національної промисловості, у порівняні 3 іншими видами економічної діяльності вона має ряд переваг, а саме: закріпленість, нерухомість, капіталоємність, матеріалоємність, тривалість створення й експлуатації та ін. У порівнянні з багатьма іншими галузями, будівництво $\epsilon$ специфічним видом проектної індустрії з певними особливостями, що впливають на характеристики побудованої продукції, способи виробництва та промисловості. Метою статті $є$ визначення основних ризиків системи економічної безпеки 
будівельного підприємства та аналіз шляхів їх ідентифікації та управління ними. Завданням цього дослідження є розробка авторського підходу щодо класифікації ризиків економічної безпеки підприємств будівельної галузі та розробка рекомендацій щодо ідентифікації та управління ризиками. Використовуючи загальні логічно-аналітичні методи, ця стаття досліджує природу особливостей діяльності підприємств будівельної та галузі різних видів ризиків, пов'язаних 3 нею. У результаті авторами запропоновано виділяти юридично-правові, фінансові, архітектурно-будівельні (виробничі), природні (екологічні) та ризики на ринку нерухомості як основні ризики економічної безпеки підприємств будівельної галузі. Зроблено висновки щодо основних особливостей діяльності будівельних підприємств та природи ризиків у їх функціонуванні.

Ключові слова: економічна безпека; будівництво; ризики; фінансові ризики; будівельні підприємства; ідентифікація ризиків.

\section{ОСНОВНЫЕ РИСКИ ЭКОНОМИЧЕСКОЙ БЕЗОПАСНОСТИ ПРЕДПРИЯТИЙ СТРОИТЕЛЬНОЙ ОТРАСЛИ, ИХ ИДЕНТИФИКАЦИЯ И УПРАВЛЕНИЕ ИМИ}

В условиях нестабильной экономической среды главной задачей менеджмента предприятий строительной отрасли становится приспособление к изменяющимся внешним условиям и уменьшения проявления негативных факторов на деятельность и ее финансовые результаты. Неопределенность влияния факторов внешней среды и отсутствие возможности осуществления достоверного прогноза экономических процессов в области порождают риск. Фактор неопределенности играет существенное влияние на деятельность строительных предприятий, обусловливает актуальность задачи повышения эффективности управления рисками на всех стадиях жизненного цикла строительной продукции. Предметом исследования в данной работе являются особенности деятельности строительных предприятий и их экономическая безопасность. Строительная отрасль является сердцевиной всей национальной промышленности, по сравнению с другими видами экономической деятельности она имеет ряд преимуществ, а именно: закрепленность, недвижимость, капиталоемкость, материалоемкость, продолжительность создания и эксплуатации и др. По сравнению со многими другими отраслями, строительство является специфическим видом проектной индустрии с определенными особенностями, которые влияют на характеристики построенной продукции, способы производства и промышленности. Целью статьи является определение основных рисков системы экономической безопасности строительного предприятия и анализ путей их идентификации и управления ими. Задачей данного исследования является разработка авторского подхода к классификации рисков экономической безопасности предприятий строительной отрасли и разработка рекомендаций по идентификации и управления рисками. Используя общие логико-аналитические методы, эта статья исследует природу особенностей деятельности предприятий строительной и области различных видов рисков, связанных с ней. В результате авторами предложено выделять юридически-правовые, финансовые, архитектурно-строительные (производственные), природные (экологические) и риски на рынке недвижимости основные риски экономической безопасности предприятий строительной отрасли. Сделаны выводы относительно основных особенностей деятельности строительных предприятий и природы рисков в их функционировании.

Ключевые слова: экономическая безопасность; строительство; риски; финансовые риски; строительные предприятия; мошенничество.

\section{Бібліографічні описи / Bibliographic descriptions}

Чех Н. О., Вершиніна Д. М., Луб А. І. Основні ризики економічної безпеки підприємств будівельної галузі, їх ідентифікація та управління ними. Сучасний стан наукових досліджень та технологій в промисловості. 2019. № 2 (8). C. 113-120. DOI: https://doi.org/10.30837/2522-9818.2019.8.113.

Chekh, N., Vershynina, D., Lub, A. (2019), "The main risks of economic security of the construction industry enterprises, their identification and management", Innovative Technologies and Scientific Solutions for Industries, No. 2 (8), P. 113-120. DOI: https://doi.org/10.30837/2522-9818.2019.8.113. 